\title{
Development of a Peace Engineering Initiative within a First-Year Engineering Program
}

\author{
Timothy Hinds ${ }^{1}$, Neeraj Buch ${ }^{2}$, Vincent Delgado ${ }^{3}$, Jenahvive Morgan ${ }^{4}$ \\ ${ }^{1}$ First-Year Engineering CoRe Experience, Michigan State University, East Lansing, Michigan \\ ${ }^{2}$ Department of Civil and Environmental Engineering, Michigan State University, East Lansing, Michigan \\ ${ }^{3}$ Residential College in the Arts and Humanities, Michigan State University, East Lansing, Michigan \\ ${ }^{4}$ First-Year Engineering CoRe Experience, Michigan State University, East Lansing, Michigan \\ ${ }^{1}$ hinds@msu.edu, ${ }^{2}$ buch@msu.edu, ${ }^{3}$ delgado1@msu.edu, ${ }^{4}$ jenahviv@msu.edu
}

\begin{abstract}
The first-year engineering program, CoRe Experience, at Michigan State University (MSU) has a long history of embedded service-learning projects within its Introduction to Engineering Design course. Service-learning projects were incorporated into the course beginning spring semester 2011 with teams of students designing and building working prototypes of assistive aids for blind, deaf and physically disabled university students and employees as well as members of the local community. The projects then migrated spring semester 2015 to a collaboration with the MSU Engineers Without Borders student organization for the design of a water filtration and heating apparatus for communities in the Dominican Republic.
\end{abstract}

Since fall semester 2018, the MSU College of Engineering has partnered with the MSU Residential College in the Arts and Humanities (RCAH) Program on Sustainability in Costa Rica to have first-year engineering students and some arts and humanities students collaborate to develop designs for community-based projects in Costa Rica. Since, its founding in 2008, RCAH has focused on community engagement as an important element of the arts and humanities.

The semester-long design project is then followed by a humanities course, Transcultural Relations, where students whom had developed designs the previous semester learn about Costa Rican history and culture, ethical theories for sustainable development and civic engagement skills. The course includes an embedded one-week education abroad experience where students travel to Costa Rica to assist local communities in the implementation of designs developed the previous semester.

The introduction to engineering design community-based project work and the transcultural relations course with the education abroad component form the basis for the MSU Peace Engineering Initiative.

Keywords: Peace engineering, first-year, design, Costa Rica

\section{Introduction}

Since 2008, the Michigan State University (MSU) First-Year Engineering CoRe (Cornerstone Engineering and
Residential) Experience (Walton, et al., 2013; Hinds et al., 2010) has offered an introductory engineering design course, EGR 100 Introduction to Engineering Design, in which students are taught the engineering design process through hands-on project work while developing their teamwork and communication skills and applying creativity to develop an appreciation for professionalism and ethics in engineering practice (Vagani and Hinds, 2008).

A major portion of the EGR 100 course has teams of 3 to 5 first-year engineering students complete an open-ended design project where teams select from a suite of projects which may be classified into 3 major project categories: general, industry-sponsored and service-learning. General projects are typically developed by the course instructor and involve a specific engineering concept. Industry-sponsored projects are proposed by our program professional partners where student teams are challenged to solve a "real" problem. Service-learning projects are those proposed by outside units or groups to address a community need.

MSU, the CoRe Experience program and EGR 100 have a long history of engaging students in service-learning engineering design projects. The following chronicles that effort.

\section{Service-Learning Project History}

Since 2011, student teams in the EGR 100 Introduction to Engineering Design course have had the option of selecting a service-learning problem as their major design project. And, we have seen the positive effects hands-on, clientbased and service-learning projects have had on student retention (Hinds, et al., 2015, Hinds, et al., 2014). During the period of spring semester 2011 and fall semester 2016, over 8800 students were enrolled in the EGR 100 course. Of those, 2245 students (over 567 teams) elected to undertake a service-learning design project. The six organizations that partnered with EGR 100 for those design projects are detailed below. A summary of the numbers of teams and total numbers of students participating is given in Table 1 . 


\section{A. MSU RCPD Projects}

Service-learning projects were first introduced into EGR 100 in spring semester 2011 with our partnering with the MSU Resource Center for Persons with Disabilities (RCPD). The RCPD assists MSU students, staff and community members with disabilities in developing solutions to perform daily life and work activities. A total of 10 student teams (38 total students) developed assistive aid solutions for clients of a local physical rehabilitation firm. Among the projects were the design and construction of an electric wheelchair charging station for a quadriplegic faculty member, an adjustable computer station and computer-controlled environment system for a disabled client at a local facility, and a utensil holder for a robotic cooking station for another wheelchair-bound client.

Fall 2011 projects included 12 student teams (52 total students) developing and delivering human anatomy teaching technology for grade-school students at the Bobbili Blind School in Andhra Pradesh, India; creating iPod Shuffle devices mounted on an adjustable work/play surface for a blind four-year-old who also has cerebral palsy; and building an award ribbon cutting machine for an impaired adult working at a local workshop facility. The spring 2012 projects had 6 EGR 100 teams (22 total students) developing assistive teaching tools at the Asian Aid School for the Deaf in Kollegal, India, so that deaf students could learn to use basic electronics and other scientific equipment and conduct experiments using written instructions as well as captioned web-based video.

In fall semester 2012, 12 teams (48 total students) combined the technologies developed in the previous 2 semesters to create fully-assistive technology for both blind and deaf students to learn basic electronics skills. The teams created captioned video instructions as well as target-based sensors that were integrated into existing commercially-available electronics educational kits to have students build and test basic electronic circuits.

The EGR 100 service-learning project relationship with RCPD continued into spring semester 2013 with 30 student teams (118 total students) participating. Projects included student teams developing assistive technologies to teach basic electronics to deaf or blind students, developing physical models to teach University physics to blind students, developing accessible public voting tools for disabled individuals as well as wheelchair mounted cell phone/iPad holders.

Fall semester 2013 had 26 student teams (101 total students) developing teaching aids for blind college students to learn multivariable calculus (initial client was an MSU engineering student); electronics instructional kits and captioned videos for deaf or blind younger students; and accessible maps of the MSU campus for blind individuals.
In spring 2014, 52 student teams (191 total students) worked on RCPD projects which included continuing to develop assistive technologies to teach basic electronics to deaf or blind students, physical models to teach university physics and multivariable calculus to blind students, and accessible MSU campus maps for blind students. Fall 2014 saw 18 student teams (75 total students) developing basic electronics instructional kits and captioned videos for deaf or blind younger students and transfer aids for wheelchairbound students using hand cycles in athletic competition.

Spring 2015 RCPD projects included 16 student teams (64 total students) developing assistive technologies to teach basic electronics to deaf or blind students as well as developing physical models to teach math to middle school students. Fall 2015 projects included 3 teams (12 total students) working on a bicycle cargo/passenger carrier for an RCPD client.

\section{B. MSU RISE Projects}

While we were developing design projects with MSU RCPD, we began a relationship with the MSU Residential Initiative on the Study of the Environment (RISE) with EGR 100 project teams developing prototypes for a University greenhouse (hoop house) heating system (see Figure 1 below). In spring 2013, a total of 15 teams (58 total students) participated in the design project. This relationship continued in fall 2013 with 20 teams (77 total students) developing working prototypes for rooftop gardening water collection and distribution systems.

The spring 2015 RISE project involved 14 student teams (56 total students) designing systems to reduce University residence hall waste.

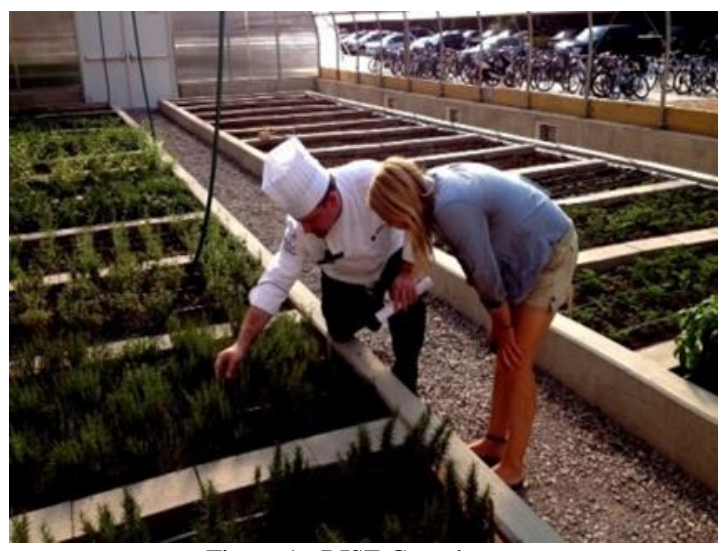

Figure 1: RISE Greenhouse

\section{MSU RCAH Projects}

A relationship between the MSU Residential College in the Arts and Humanities (RCAH) and EGR 100 began summer 2013 where a combined 11 engineering and arts students spent an intensive week-long course, UGS 103 Cultures of Creativity, exploring the connections between art, engineering and culture by visiting art studios, design houses, manufacturing firms, etc. in the Detroit, Michigan area. This 
Journal of Engineering Education Transformations, Volume 33, January 2020, Special issue, eISSN 2394-1707 program then continued with those same 11 students, joined by 2 additional students, being placed in a special section of the EGR 100 course fall semester 2013. The 13 students (6 engineering and 7 arts) then worked on a joint design project for a local, non-profit vocational rehabilitation firm, Peckham Industries, where they designed and built a system for visitors to view a $40 \mathrm{ft}(12.2 \mathrm{~m}) \times 200 \mathrm{ft}(61.0 \mathrm{~m})$ wall containing rehabilitation client paintings as well as recorded individual artist vignettes. Much of this, and subsequent, work was made possible by grants from the Ford Motor Company Foundation Community Corps program.

This same program repeated summer 2014 with 14 total students ( 7 engineering and 7 arts) participated in the UGS 103 course. In fall 2014,9 of those students (6 engineering \& 3 arts) worked on a joint design project again with the local vocational rehabilitation firm to design and construct portable art structures to be placed at abandoned manufacturing sites. Some of the artwork was developed by local grade-school children participating in programming developed and delivered by the 9 MSU students. A majority of the artwork was created by formerly adjudicated youth participating in a program at the rehabilitation firm.

The EGR 100 / RCAH / UGS 103 study away program continued summer 2015 where a combined 14 engineering and arts students again spent an intensive week of study in the Detroit area. During fall semester 2015, 12 of those students ( 8 engineering \& 4 arts) worked on a joint design project with students at the Paul Robeson Malcolm X Academy in Detroit. The project had students design and build a portable art studio to engage Detroit area youth. The "studio" was constructed using a 1937 Ford firetruck which may be driven to schools and events in the area. The portable art studio is shown in Figure 2.

In fall semester 2016, 4 EGR 100 teams (16 total students) developed and built a recreational bench/patio using straw bale construction techniques.

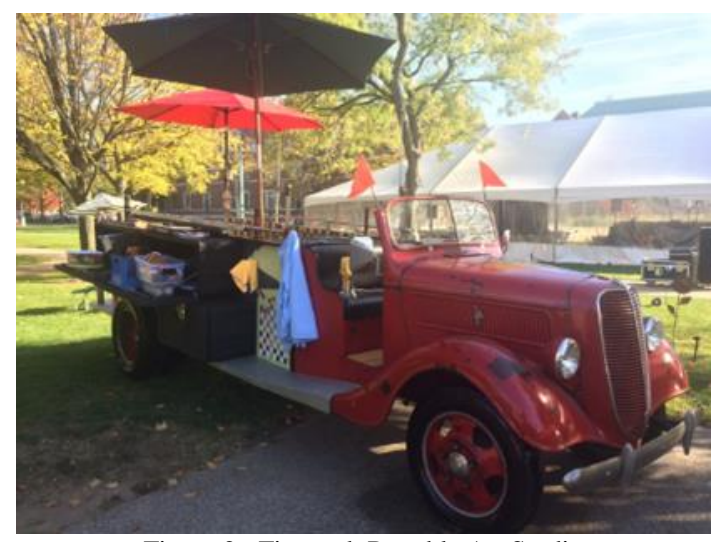

Figure 2: Firetruck Portable Art Studio

D. MSU Engineers Without Borders Projects

In spring 2015, EGR 100 partnered with the MSU Engineers Without Borders (EWB) student organization to design systems for usage around the globe. The spring 2015 EWB projects had 52 teams (206 total students) designing solar water heaters, 29 teams (116 total students) developing water filtration systems and 5 teams (20 total students) developing assessment methods for composting latrines. Projects continued fall 2015 with 140 teams (560 total students) developing water collection, purification and heating systems for use in the Dominican Republic. The spring 2016 EWB project involved 24 student teams (96 total students) designing portable bridge systems for usage in high-volume rain regions of the world.

\section{E. MSU ASRC Projects}

Fall semester 2015 saw a new relationship developed with the MSU Adaptive Sports and Recreation Club (ASRC). This group assists physically impaired MSU students who compete with similar students at other institutions in athletic competitions. A total of 9 teams (33 total students) designed and built working prototypes of throwing chair stabilizers, wheelchair toe guards and hand cycle pedal adapters. Spring 2016 ASRC projects included 6 student teams (24 total students) developing assistive technologies to allow student athletes with physical impairments to use walkers to compete in races. Fall 2016 projects included 4 teams (16 total students) working on a wheelchair support system for ASRC athletes competing in throwing events and spring 2017 had 4 teams (16 total students) developing a wheelchair transfer aid.

\section{F. MSU REHS Projects}

EGR 100 has also partnered with the MSU Residence Education and Housing Services (REHS) unit to develop engineering solutions to campus projects. Spring 2016 saw 27 teams (105 total students) designing systems to assist University students with the residence hall move-in and move-out processes. Fall 2016 projects then had another 18 teams (72 total students) working on continuation of the residence hall move-in/move-out project, with spring 2017 involving 8 teams (32 total students) on a design of a movein traffic plan.

\begin{tabular}{|c|c|c|c|c|c|c|}
\hline \multicolumn{7}{|c|}{ Table 1. Service-Learning Project Teams (Numbers of S tudents) } \\
\hline Org/S em & RCPD & RISE & RCAH & EWB & AS RC & REHS \\
\hline Spring 2011 & $10(38)$ & & & & & \\
\hline Fall 2011 & $12(52)$ & & & & & \\
\hline Spring 2012 & $6(22)$ & & & & & \\
\hline Fall 2012 & $12(48)$ & & & & & \\
\hline Spring 2013 & $30(118)$ & $15(58)$ & & & & \\
\hline Fall 2013 & $26(101)$ & $20(77)$ & $2(13)$ & & & \\
\hline Spring 2014 & $52(191)$ & & & & & \\
\hline Fall 2014 & $18(75)$ & & $2(9)$ & & & \\
\hline Spring 2015 & $16(64)$ & $14(56)$ & & $86(342)$ & $9(33)$ & \\
\hline Fall 2015 & & & $2(12)$ & $140(560)$ & $6(24)$ & $27(105)$ \\
\hline Spring 2016 & & & & $24(96)$ & & \\
\hline Fall 2016 & & & $4(16)$ & & $4(15)$ & $18(72)$ \\
\hline Spring 2017 & & & & & $4(16)$ & $8(32)$ \\
\hline
\end{tabular}

\section{MSU Peace Engineering Development}


In fall 2018, EGR 100 began working with the MSU RCAH Program on Sustainability in Costa Rica to develop design projects with Costa Rican community partners. Two separate projects were initiated with 9 teams (37 total students). The first project involved the design of a community park for the youth and the elderly in the village of Shiroles, located in the Limon Province. The community park was to be an outdoor learning facility that included a playground, permaculture garden, edible forest, etc. with its design incorporating local conditions such as weather, water and climate. Teams incorporated client needs and local practices into their designs. Local partners in the project included Vecinos de Los Shiroles, La Escuela de Los Shiroles, and La Asociacion Centro Indigena de Formacion, Capacitacion y Recreacion. Figure 3 shows one of the early proposed design sketches.

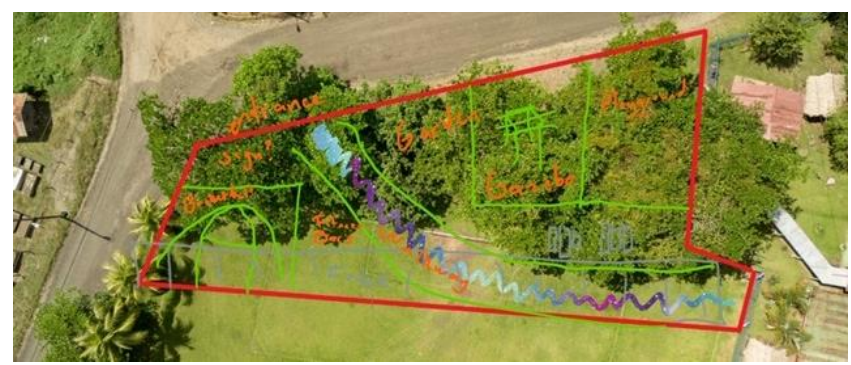

Figure 3: Shiroles Community Park Preliminary Student Design Notes

The second project concerned the development of a site plan for a new educational center for the Girls for Success program in Hone Creek, also in the Limon Province. This program offers 16 indigenous Kolkoldi girls, aged 7 to 12 years, the opportunity to further their learning in a daily after-school program. For 3 hours each day, instructors work with the students on English as well as other academic skills. The program is operated by a partnership between the El Yue Center for International Peace, an indigenous woman's cooperative, and the Indiana-based Peace Through Yoga Foundation. The site plan included design of the school structure, landscaping, future bungalow location for the program instructor, gardens and play area. Teams focused on incorporating client needs and local practices into their designs. A proposed playground design is shown in Figure 4.

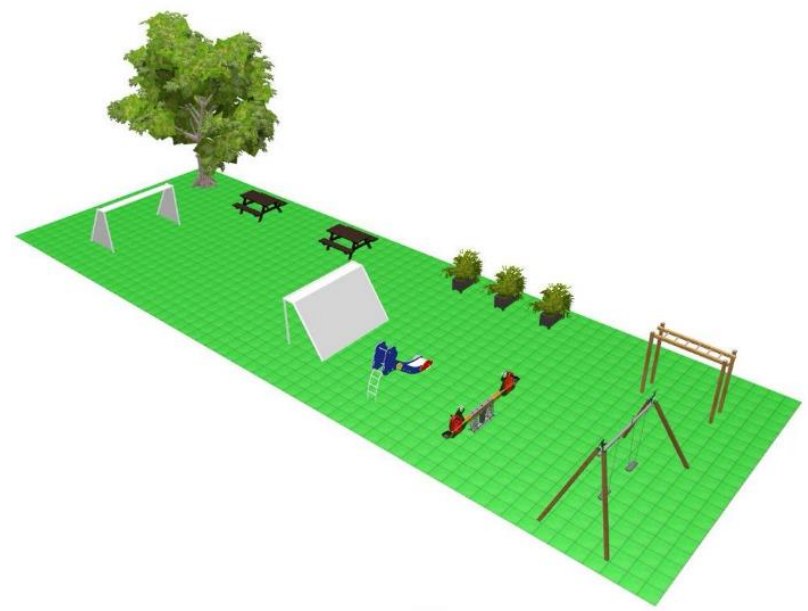

Figure 4: Girls for Success School Playground Design

Following the design work that was completed by the student teams fall 2018, interested students were encouraged to enroll in a second course related to the Costa Rican projects. This course, IAH 211C Area Studies Americas - Culture, Sustainability and Everyday Life in Costa Rica, was taken by 10 engineering students, 7 of which had been involved with the Shiroles park or Hone Creek playground design projects. In this course, students investigated key concepts, insights and skill sets in ethics, Costa Rican history and culture, sustainability and civic engagement. The course had students consider three narratives about sustainability in Costa Rica: Costa Rica as eco-paradise, Costa Rica as exception, and Costa Rica as both challenged and supported by globalization and neoliberalism. The course also included a one-week education abroad experience where students travelled to the Shiroles/Hone Creek area to work with community leaders on projects related to the park and playground designs. This included the construction of a community garden (huerta) to produce vegetables to be used at a local elementary school as shown in Figure 5.

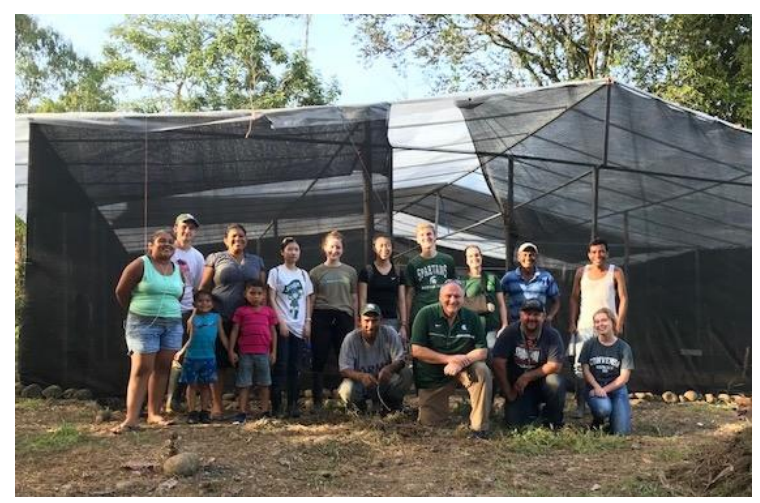

Figure 5: Shiroles Community Garden Construction

Also constructed was a portion of the playground at the Girls for Success school in Hone Creek shown in Figure 6.

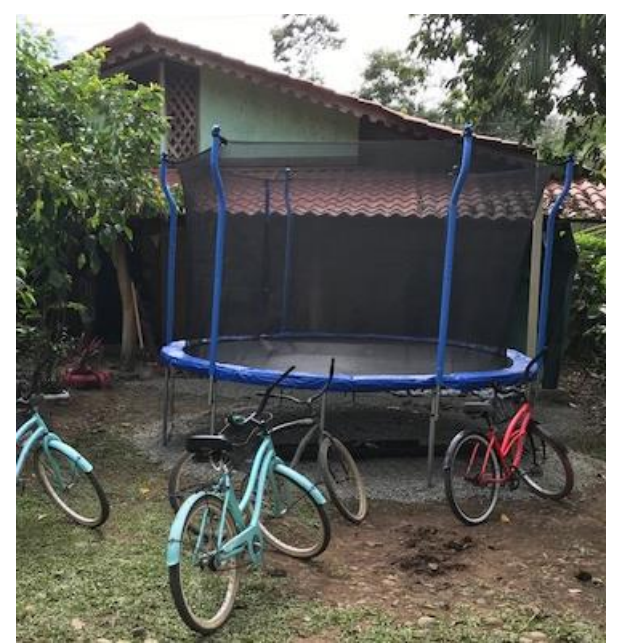

Figure 6: Girls for Success School Playground Construction

The 2018-19 year of EGR 100 Costa Rica design projects followed by the IAH $211 \mathrm{C}$ course on Costa Rican studies 
Journal of Engineering Education Transformations, Volume 33, January 2020, Special issue, eISSN 2394-1707 and education abroad experience became the foundation for the MSU Peace Engineering initiative. For spring semester 2019, another community-based project was identified with seed funding obtained through the MSU Network for Global Civic Engagement. The project was the design of an ecolodge to be used as an educational center and housing facility in Monteverde, Costa Rica. The eco-lodge was to be located at and used by LIFE (Low Impact For Earth) Monteverde, an agriculture and nature conservation association that operates a 42-acre sustainable coffee plantation. The association conducts environmental educational activities for residents and visitors where they teach strategies to reduce environmental impact in the coffee production process. Six teams of EGR 100 students (24 total students) developed and presented several design options for the proposed eco-lodge. One of the conceptual designs is shown in Figure 7.

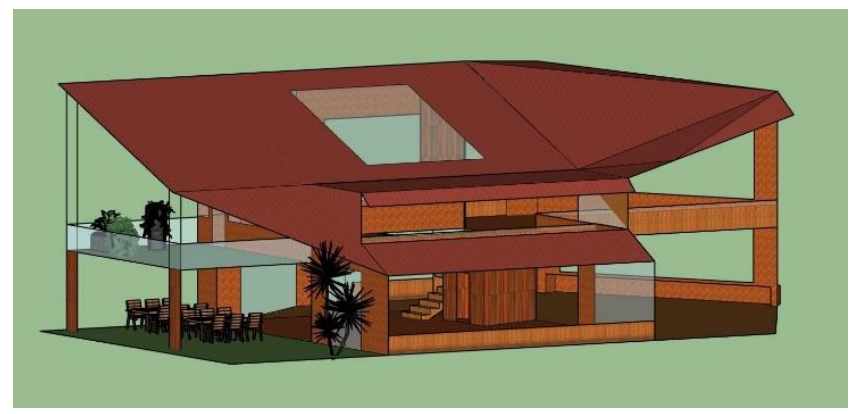

Figure 7: LIFE Monteverde Eco-Lodge Concept Design

The MSU Peace Engineering initiative has become a 2course sequence with students first completing an international project in the introductory engineering design course followed by a second humanities course in which students learn about area culture and complete a one-week education abroad experience constructing a portion of their previous design work. For fall semester 2019 (the current academic semester as of the writing of this paper), IAH $211 \mathrm{C}$ was replaced by RCAH 203 Transculturation through the Ages: Designing for Peace. This course attempts to answer the question:

Given the challenges of global conflict, globalization, climate change and sustainability, how should we design for peace and human security?

This complex question calls for engineers, designers and other change makers to identify, design and implement creative solutions to human conflicts - solutions that can radically transform and improve human and natural wellbeing. In other words, it calls us to design for a sustained peace. This objective radically challenges the work of engineers, artists and change makers to complicate and reconsider their work with questions such as:

-What is the nature of these complex problems?

- How do these problems challenge us to reconceptualize our practice as designers, engineers, artists and community change makers?

- How might new ideas about design, engineering, the arts and community change, as well as an expanded understanding of technology, help us consider new ways of designing for peace and human security?
In this course, there are currently 15 engineering students, 4 of which had worked on the LIFE Monteverde design project the previous semester. These students will participate in a one-week education abroad experience in Costa Rica at the end of the semester where they will assist LIFE Monteverde with the initial construction of the eco-lodge.

\section{MSU Peace Engineering Future Plans}

The EGR 100 Introduction to Engineering Design course is an integral piece of the MSU College of Engineering curricula and will be offered each fall and spring semester. Student teams will continue to have the opportunity to select a community-based, open-ended design project. Our intent, through the assistance of the MSU Network for Global Civic Engagement, is to expand the international project options and subsequent education abroad opportunities embedded in the RCAH 203 course beyond Costa Rica to communities in other countries needing engineering design and implementation assistance.

We will also add a third course, RCAH 202 The Presence of the Past, to our Peace Engineering initiative. The model for this introduction to Peace Engineering is the truth and reconciliation process that has been created in more than 40 countries worldwide over the past 30 years. Through this process, communities that have suffered through violent conflict are able to tell their stories, regain their dignity, restore health, and move toward a more lasting, just peace. Students will use digital technology, video animations, and other communication tools to connect with local refugee communities and communities abroad to help them with the design of their plans for a more lasting peace through truth and reconciliation.

Students in the RCAH/EGR Peace Engineering Initiative engage together and with communities around the world to: Collaborate with interdisciplinary and diverse communities on design problems (sections of EGR 100 for Engineers, RCAH 326 Topics in Community Engagement for RCAH students); Use Peace Engineering to understand and respond to complex social and technological challenges (RCAH 203, satisfies university Integrative Studies in the Arts and Humanities (IAH) requirements for both engineers and RCAH students); and use digital and other communication tools to co-design a lasting peace in communities using truth and reconciliation.

RCAH has developed a model for civic engagement that is used with more than 37 community partnerships worldwide. It now requires that all student graduate with course work and practical experience in arts- and humanities-based civic engagement methodologies. The college, with its majority of faculty public scholars with backgrounds in peace and justice studies, facilitated the redevelopment of the University's peace and justice studies minor.

\section{Conclusions}

Solutions to some of world's most difficult problems require the ability to collaborate across diverse and interdisciplinary groups of people - from engineers to artists to communities. 
For engineers concerned with effective, sustained solutions this means understanding root causes related to power, inequity, justice and other difficult questions; listening deeply; engaging in difficult conversations; telling clear stories; and resolving conflicts. Peace Engineering uses engagement, engineering and collaboration to respond to difficult social and technological challenges and build peace.

\section{Acknowledgement}

The authors wish to thank MSU Resource Center for Persons with Disabilities, the MSU Residential Initiative on the Study of the Environment, the MSU Residential College in the Arts and Humanities, the MSU Engineers Without Borders student organization, the MSU Adaptive Sports and Recreation Club, the MSU Residence Education and Housing Services and the MSU RCAH Program on Sustainability in Costa Rica for their support of the many design projects. This work was also supported in part by a grant from the MSU Network for Global Civic Engagement.

\section{References}

Walton, S., Hinds, T., Urban-Lurain, M., Briedis, D., DavisKing, C. and Wolff, T. (2013) Building the Whole Engineer: An Integrated Academic and Co-Curricular First-Year Experience, Proceedings of 2013 American Society for Engineering Education (ASEE) Annual Conference and Exposition, First-Year Programs Division, June 23-26, 2013, Atlanta, GA, 2013-7410.

Hinds, T., Idema, A., Davis-King, C., Buch, N. and Wolff, T. (2010) First-Year Engineering: A Comprehensive Approach, Proceedings of 2010 American Society for Engineering Education (ASEE) Annual Conference and Exposition, First Year Programs Division, June 20-23, 2010, Louisville, KY, 2010-1502.

Vagani, M. and Hinds, T. (2008) The Importance of HandsOn Projects in a First-Year Course, Proceedings of 2008 American Society for Engineering Education (ASEE) North Central Section Conference, March 28-29, 2008, Wright State University, Dayton, $\mathrm{OH}$.

Hinds, T., Christlieb, S., Walton, S., Urban-Lurain, M. and Briedis, D. (2015) The Effects of First-Year Client-Based Projects on Student Retention, Proceedings of 7th Annual First-Year Engineering Experience (FYEE) Conference, August 3-4, 2015, Roanoke, VA, Session T1A.

Hinds, T., Christlieb, S., Walton, S., Urban-Lurain, M. and Briedis, D. (2014) Determining the Influence of First-Year Service Learning Projects on Student Retention,

Proceedings of 6th Annual First-Year Engineering Experience (FYEE) Conference, August 7-8, 2014, College Station, TX, Session F4B. 